\title{
Analisis Kesiapan Guru dalam Penulisan dan Publikasi Karya Tulis Ilmiah
}

\author{
Syarifuddin* \\ STKIP Bima, Bima, Indonesia \\ *Coresponding Author: syarifuddin.stkipbima@gmail.com \\ Dikirim: 27-05-2021 ; Direvisi: 28-05-2021 ; Diterima: 28-05-2021
}

\begin{abstract}
Abstrak: Penelitian ini bertujuan untuk mengetahui kesiapan guru dalam menghasilkan dan mempublikasikan karya tulis ilmiah, baik dalam bentuk artikel ilmiah, laporan hasil penelitian, buku, dan jenis karya tulis ilmiah lainnya. Penelitian menggunakan pendekatan kualitatif deskriptif. Subjek penelitian adalah 23 orang guru yang terdiri dari guru sekolah dasar, guru sekolah menengah pertama, dan guru sekolah menengah atas, serta guru madrasah sederajat yang berada di wilayah kabupaten Bima yang bersedia memberikan tanggapan saat dilakukan penelitian. Instrumen yang digunakan dalam pengumpulan data adalah sebanyak 14 butir yang terdiri dari pertanyaan pilihan dan jawaban singkat. Pertanyaan tersebut disusun dalam bentuk google form dan edarkan secara online melalui media sosial whatsapp dan media sosial lainnya. Analisis data dengan mendeskripsikan pilihan jawaban maupun jawaban singkat dari responden kemudian mengelompokkannya berdasarkan kategori jawaban. Penelitian ini menunjukan tingkat kesiapan guru dalam menghasilkan karya tulis ilmiah masih rendah. Demikian juga dalam kesiapan maupun pengetahuan guru dalam mempublikasikan karya tulis ilmiah masih dalam kategori rendah. Porsentase guru yang pernah melakukan publikasi hasil penelitian sebesar $30.4 \%$, dan porsentase guru yang pernah melakukan publikasi dalam bentuk buku hanya $8.7 \%$. Porsentase tersebut berada pada kategori yang masih rendah.
\end{abstract}

Kata Kunci: kesiapan guru; karya tulis ilmiah; publikasi

Abstract: This study aims to determine the readiness of teachers in producing and publishing scientific papers, both in the form of scientific articles, research reports, books, and other types of scientific writing. The research used a descriptive qualitative approach. The research subjects were 23 teachers consisting of elementary school teachers, junior high school teachers and high school teachers, as well as madrasah teachers in the district of Bima who were willing to provide responses when the research was conducted. The instruments used in data collection were 14 items consisting of selected questions and short answers. The questions are compiled in the form of a google form and circulated online through Whatsapp social media and other social media. Data analysis by describing the answer choices and short answers from the respondent then grouping them according to the answer category. This study shows the level of teacher readiness in producing scientific writing is still low. Likewise, the readiness and knowledge of teachers in publishing scientific papers is still in the low category. The percentage of teachers who had published research results was $30.4 \%$, and the percentage of teachers who had published in the form of books was only $8.7 \%$. This percentage is in the low category.

Keywords: teacher readiness; scientific papers; publication

\section{PENDAHULUAN}

Guru memiliki tugas utama sebagai pendidikan, pengajar, memberikan bimbingan, melatih, menilai, dan melakukan evaluasi terhadap perkembangan peserta didik (Undang-undang RI Nomor 14, 2005; Permenpanrb Nomor 16, 2009). 
Guru profesional adalah yang memiliki kompetensi atau keterampilan yang disyaratkan dalam melakukan tugasnya sebagai pendidik dan pengajar (Kunandar, 2007). Dalam hal ini bahwa prinsip profesionalitas guru adalah dengan mengembangkan kompetensi dan kualifikasi akademik secara berkelanjutan yang sejalan dengan perkembangan dan kemanjuan ilmu pengetahuan, teknologi, dan seni sesuai bidang keilmuan yang ditekuni masing-masing guru. Dalam menjalankan tugasnya, guru mendapat beban kerja setara dengan 24 jam pelajaran (tatap muka) dan paling banyak 40 jam pelajaran (Permenpanrb Nomor 16, 2009).

Implikasi dari hal tersebut di atas adalah guru dapat memperoleh pengakuan atau kenaikan jabatan fungsional (pangkat/golongan) secara berkala oleh pemerintah melalui tim penilai angka kredit. Dalam peningkatan jabatan fungsional tersebut, ada 4 (empat) unsur utama yang menjadi penilaian angka kredit (Permenpanrb Nomor 16, 2009) yaitu 1) pendidikan yang meliputi pendidikan formal (memperoleh ijasah) dan pendidikan prajabatan; 2) pembelajaran atau bimbingan yang meliputi pelaksanaan pembelajaran bagi guru kelas dan guru mata pelajaran, dan pelaksanaan bimbingan bagi guru konseling; 3) pengembangan profesi berkelanjutan meliputi pengembangan diri, publikasi ilmiah, dan karya inovatif; dan 4) penunjang tugas guru yang meliputi memperoleh ijasah yang tidak sesuai dengan bidang, memperoleh penghargaan atau tanda jasa, dan melaksanakan tugas pendukung lainnya.

Unsur pertama dan kedua merupakan kegiatan rutin yang dilakukan oleh guru disekolah, sementara unsur ketiga dan keempat merupakan kegiatan yang memerlukan keterampilan tambahan yang harus dimiliki oleh guru. Akan tetapi, pada unsur ketiga dan keempat tersebut perlu upaya keras dari guru agar dapat memenuhi dan melaksanakannya, terutama dalam menunjang kenaikan jabatan fungsional maupun pangkat/golongan. Seorang guru yang akan mengajukan kenaikan pangkat diwajibkan untuk melakukan publikasi ilmiah (Permenpan Nomor 16, 2009). Publikasi ilmiah ini dapat berupa publikasi karya tulis ilmiah (KTI), baik berupa buku, maupun publikasi hasil penelitian. Ada beberapa jenis KTI yang dapat disusun oleh guru dalam memenuhi Permenpan tersebut, yaitu 1) Penelitian tindakan kelas; 2) Penelitian eksperimen dalam lingkup kerja; 3) Penelitian deskriptif; 4) Laporan kegiatan atau karya untuk memecahkan masalah dalam lingkup kerja); 5) Gagasan ilmiah dalam bidang pekerjaannya; 6) Prasaran yang disajikan pada forum ilmiah; 7) Buku pembelajaran (sesuai bidang kerja); 8) Modul pembelajaran; 9) Tulisan ilmiah populer dibidang pendidikan; 10) Artikel ilmiah dalam bidang pendidikan dan pembelajaran pada satuan pendidikannya; 11) Diktat pelajaran; 12) KTI hasil terjemahan.

Karya tulis ilmiah yang sering dilakukan oleh guru berupa laporan hasil penelitian tindakan kelas (PTK) dan banyak dilakukan untuk memenuhi unsur penunjang publikasi. Untuk beberapa jenis penelitian lainnya (misanya: penelitian eksperimen atau pengembangan) belum banyak dilakukan. Publikisi karya tulis ilmiah dalam bentuk buku maupun karya inovasi lainnya belum menjadi target oleh kebanyakan guru.

Seiring perkembangan ilmu pengetahuan dan teknologi, maka proses menghasilkan karya tulis ilmiah dan cara mempublikasikannya dipengaruhi oleh sistem yang terintegrasi dengan teknologi. Misalnya karya ilmiah yang dipadukan dengan penerapan teknologi dan mempublikasikannya melalui sistem atau aplikasi online seperti open journal sistem (OJS). Menghasilkan karya tulis ilmiah dan cara 
mempublikasikannya tidaklah mudah. Guru yang tidak terbiasa melakukan hal tersebut tentu memiliki banyak kendala dan alasan yang berbeda-beda dan mendasar sebagai penghalang dalam menghasilkan karya tulis ilmiah. Sehingga perlu dilakukan upaya atau kegiatan yang melibatkan guru dalam peningkatan pengetahuan tentang karya ilmiah dan cara mempublikasikannya. Untuk itu, perlu dilakukan penelitian awal tentang kesiapan guru dalam penulisan dan publikasi karya tulis ilmiah.

\section{METODE PENELITIAN}

Penelitian ini merupakan penelitian kualitatif dengan menggunakan pendekatan deskriptif yang bersifat eksploratif.

\section{Subjek Penelitian}

Subjek penelitian ini terdiri dari guru sekolah dasar, guru sekolah menengah pertama, dan guru sekolah menengah atas, serta guru madrasah sederajat yang berada di wilayah kabupaten Bima yang bersedia memberikan tanggapan saat dilakukan penelitian. Adapun jumlah subjek yang terlibat adalah sebanyak 23 orang guru. Target subjek yang dapat berpartisipasi dalam penelitian terkendala pada kurangnya partisipasi guru dalam meluangkan waktu untuk mengisi link google form yang telah disediakan.

\section{Pengumpulan Data}

Instrumen yang digunakan dalam pengumpulan data adalah sebanyak 14 butir yang terdiri dari pertanyaan pilihan dan jawaban singkat. Ada 3 (tiga) fokus utama dari instrument tersebut yaitu masalah guru melakukan penelitian tindakan kelas (PTK), masalah publikasi hasil penelitian, dan masalah publikasi buku. Pertanyaan tersebut disusun dalam bentuk google form dan berkoordinasi dan meminta bantuan kepada pengawas satuan pendidikan dan kepala sekolah untuk diedarkan secara online melalui media sosial whatsapp dan media sosial lainnya.

\section{Analisis Data}

Analisis data dengan mendeskripsikan pilihan jawaban maupun jawaban singkat dari responden kemudian mengelompokkannya berdasarkan kategori jawaban. Adapun kategori tersebut dapat dilihat pada Tabel 1.

Tabel 1. Kategori guru menghasilkan dan mempublikasikan karya tulis ilmiah

\begin{tabular}{|c|c|l|}
\hline No. & Interval & \multicolumn{1}{|c|}{ Kategori } \\
\hline 1 & $85 \leq \mathrm{X} \leq 100$ & Sangat Tinggi \\
\hline 2 & $70 \leq \mathrm{X} \leq 84,9$ & Tinggi \\
\hline 3 & $55 \leq \mathrm{X} \leq 69,9$ & Cukup Tinggi \\
\hline 4 & $35 \leq \mathrm{X} \leq 54,9$ & Kurang \\
\hline 5 & $0 \leq \mathrm{X} \leq 34,9$ & Rendah \\
\hline
\end{tabular}

\section{HASIL DAN PEMBAHASAN}

Hasil penelitian ini berupa data yang diserap dari hasil pengisian google form yang dilakukan oleh 23 orang guru yang berupa diagram lingkaran yang menunjukan porsentase dari pilihan jawaban yang diberikan oleh responden, dan berupa jawaban singkat dari responden (guru) untuk memperkuat kategori porsentase pilihan. 
Adapun sebaran guru yang memberikan respons ditingkat satuan pendidikan seperti ditunjukan pada Gambar 1. Guru SMP/MTs memberikan respons terbanyak yaitu sebanyak 52.2\%, kemudian guru SD/MI sebanyak $26.1 \%$, sedangkan guru SMA/SMK/MA hanya $21.7 \%$. Tingkat partisipasi guru dalam memberikan respons masih tergolong rendah.

Tingkat Satuan Pendidikan tempat mengajar

23 responses

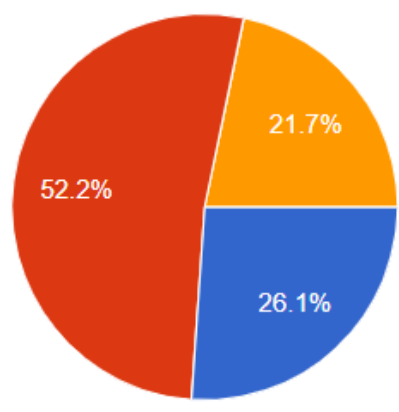

$\mathrm{SD} / \mathrm{Ml}$

SMP/MTS

SMA/SMK/MA

Gambar 1. Porsentase guru yang melakukan PTK.

Guru terbiasa melakukan penelitian tindakan kelas (PTK) dan jarang melakukan penelitian jenis lain. Hasil penelitian hanya berupa laporan dan jarang guru mempublikasikan hasil penelitiannya ke jurnal-jurnal untuk menyebarkan hasil penelitian tersebut. Kasus ini terlihat dari respon yang diberikan oleh guru yang dapat dilihat pada Gambar 2, Gambar 3, dan Gambar 4.

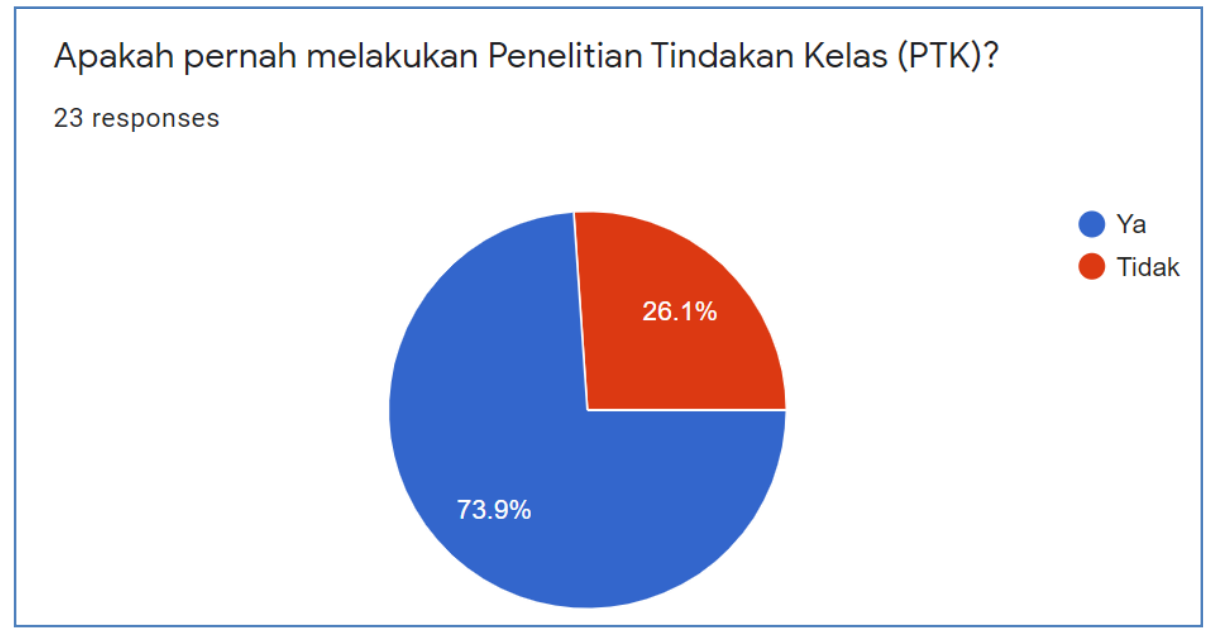

Gambar 2. Porsentase guru yang melakukan PTK.

Sebanyak $73.9 \%$ guru melakukan PTK dan $26.1 \%$ guru tidak pernah melakukan PTK. Guru yang tidak pernah melakukan PTK ini adalah guru yang memilih jawaban melakukan penelitian jenis lain dan guru yang sama sekali tidak pernah melakukan penelitian jenis lainnya. Kemudian pada Gambar 2 menunjukan tentang publikasi yang dilakukan oleh guru dari hasil penelitian atau publikasi lainnya. 
Apakah hasil penelitian (PTK atau penelitian jenis lain) pernah dipublikasikan pada jurnal ilmiah?

23 responses
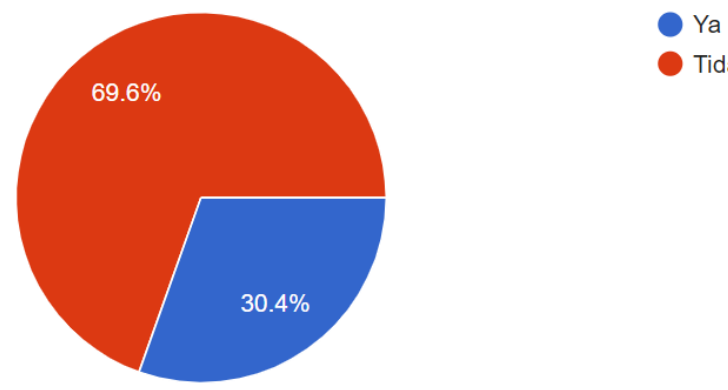

Tidak

Gambar 3. Porsentase guru melakukan publikasi hasil penelitian.

Dari Gambar 2 menunjukan hanya 30.4\% guru pernah melakukan publikasi hasil penelitiannya, sedangkan $69.6 \%$ tidak pernah melakukan publikasi hasil penelitian. Dari hasil ini bahwa masih besar porsentase guru yang tidak pernah melakukan publikasi. Hal ini juga sejalan dengan porsentase guru yang melakukan publikasi atau menulis buku pada Gambar 3. Hanya 8.7\% guru yang pernah menulis dan menerbitkan buku, sedangkan dominasi guru sebesar 91,3\% guru tidak pernah menulis dan menerbitkan buku.

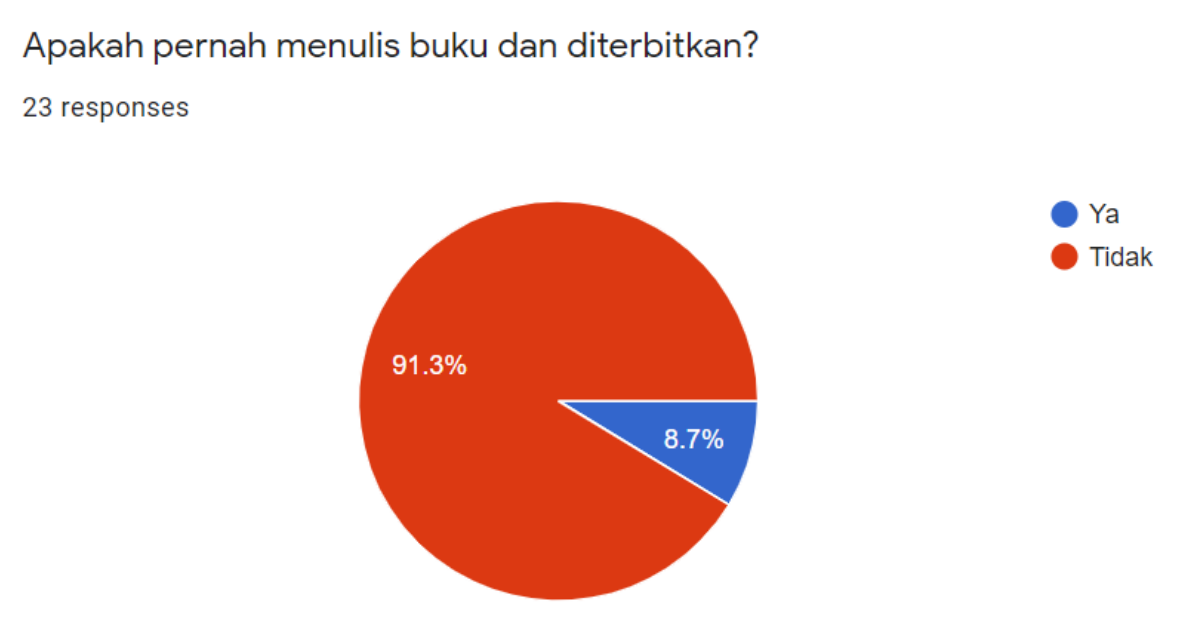

Gambar 4. Porsentase guru yang pernah menerbitkan buku

Porsentase guru yang pernah melakukan publikasi hasil penelitian dan publikasi buku yang dikonsultasikan dengan Tabel 1 maka berada pada kategori rendah. Sesuai dengan hasil kajian Rochmad dkk (2016) menyebutkan bahwa penulisan karya tulis ilmiah dan publikasi masih sangat rendah. Hal ini disebabkan oleh beberapa faktor dan ini terlihat dari jawaban singkat yang diberikan oleh beberapa respondes, diantaranya:

- Akses untuk publikasi karya ilmiah terbatas.

- Tidak ada pembimbing

- Tidak mengetahui cara mempublikasikan hasil penelitian 
- Tidak dikembangkan dalam penulisan sistematis, karena hanya dilakukan penelitian sederhana/bentuk note untuk guru saja

- Sarana dan prasarana pendukung yang kurang memadai

- Belum pernah membuat karya ilmiah

- Masalah dalam mengumpulkan bahan penelitian dan pembuktiannya

- Karna Tidak pernah mencoba

- Dalam merangkaikan kalimat sehingga kalimat itu sangat berkesinambungan

- Kurangnya pengetahuan dan pengalaman dalam bidang karya tulis

- Kurangnya wawasan dlm membuat artikel/buku serta kemauan yg kurang mendukung.

- Keinginan untuk memulai menulis buku

- Susah publikasi nya.

- Masalah dan kendalanya adalah ketersediaan bahannya kurang memadai terutama pada saat melakukan kegiatan penelitian antara lain biaya juga termasuk

Faktor tersebut sesuai dengan hasil penelitian Noorjannah (2015) yaitu motivasi menulis yang masih rendah, waktu yang terbatas, pemahaman tentang teknik penulisan yang masih kurang, gagap teknologi, buku referensi yang sangat kurang, banyaknya jasa pembuatan karya tulis, kegiatan MGMP tidak ada pembahasan masalah penulisan karya tulis, dan tidak ada pembinaan dari sekolah/lembaga. Kesulitan dalam menghasilkan karya tulis ilmiah dapat menyebakan guru frustasi dan guru melakukan mogok menulis (Hamidsyukrie dkk, 2020).

\section{KESIMPULAN}

Penelitian ini menunjukan tingkat kesiapan guru dalam menghasilkan karya tulis ilmiah masih rendah. Demikian juga dalam kesiapan maupun pengetahuan guru dalam mempublikasikan karya tulis ilmiah masih dalam kategori rendah. Porsentase guru yang pernah melakukan publikasi hasil penelitian sebesar $30.4 \%$, dan porsentase guru yang pernah melakukan publikasi dalam bentuk buku hanya $8.7 \%$. Porsentase tersebut berada pada kategori yang masih rendah.

\section{DAFTAR PUSTAKA}

Hamidsyukrie, Z. R., Syafruddin, S., \& Muntari, M. (2020). Pendampingan Penyusunan Karya Tulis Ilmiah Bagi Guru-Guru SMA/MA di Kecamatan Narmada Lombok Barat. Jurnal Pengabdian Magister Pendidikan IPA, 3(2), 137-141.

Kunandar. (2007). Guru Profesional Implementasi Kurikulum Tingkat Satuan Pendidikan (KTSP) dan Persiapan Menghadapi Sertifikasi Guru. Jakarta: PT Raja Grafindo Persada.

Noorjannah, L. (2015). Pengembangan profesionalisme guru melalui penulisan karya tulis ilmiah bagi guru profesional di SMA Negeri 1 Kauman Kabupaten Tulungagung. Jurnal Humanity, 10(1), 97-114. 
Permenpanrb Nomor 16. (2009). Tentang Jabatan Fungsional Guru dan Angka Kreditnya. Kementerian Pendayagunaan Aparatur Negara dan Reformasi Birokrasi. Jakarta.

Rochmad, R., Agoestanto, A., \& Kharis, M. (2016). Meningkatkan Kualitas Penulisan Karya Ilmiah Guru-Guru Sekolah Menengah Atas di Parakan Temanggung. Rekayasa: Jurnal Penerapan Teknologi dan Pembelajaran, 14(1), 61-66.

Undang-undang RI Nomor 14. (2005). Tentang Guru dan Dosen. Dewan Perwakilan Rakyat Republik Indonesia dan Presiden Republik Indonesia. Jakarta. 